\title{
DETERMINATION OF DIESEL ENGINE PERFORMANCE FUELED BIODIESEL (RUBBER SEED/PALM OIL MIXTURE) DIESEL BLEND
}

\author{
Ibrahim K. Adam ${ }^{1}$, A. Rashid A. Aziz ${ }^{2}$ and Suzana Yusup ${ }^{3}$ \\ ${ }^{1,2}$ Mechanical Engineering Department \\ Universiti Teknologi PETRONAS \\ 31750, Tronoh, Perak, Malaysia \\ *Email: himakh80@gmail.com \\ Phone: +60189588336 \\ ${ }^{3}$ Chemical Engineering Department \\ Universiti Tecknologi PETRONAS \\ 31750, Tronoh,Perak, Malaysia
}

\begin{abstract}
In this study the effect of speed, load and blend ratio on the performance of a multicylinder indirect injection diesel engine has been determined. Rubber seed/palm oil mixture at an equal blend ratio (50:50 vol. \%) was used for biodiesel production with the motivation of cost reduction and properties enhancement. The oil acid value of 33.4 $\mathrm{mg} \mathrm{KOH} / \mathrm{g}$ oil was reduced to $1.42 \mathrm{mg} \mathrm{KOH} / \mathrm{g}$ oil via an esterification process followed by transesterification using a hydrodynamic cavitation reactor. Blends of 5-20 vol. \% biodiesel to diesel fuel were prepared. A statistical tool, Box-Behnken design (BBD) based on response surface methodology was used to predict and to assess the combined effects of variables (speed, load and blend) on the responses, such as torque, power, brake specific fuel consumption (BSFC) and brake thermal efficiency (BTE). The load was found to be the most influential variable both individually and in combination compared to the speed and blend. A strong effect of speed over the responses was noticed except for torque, whereas its combined effect was insignificant except for BSFC and BTE. No significant contribution was observed for the blend over the response except for torque. Furthermore, the models developed fitted the experimental results of all the responses investigated.
\end{abstract}

Keywords: Response surface methodology; performance; biodiesel; rubber seed oil; palm oil.

\section{INTRODUCTION}

Concerns about clean energy and fossil fuels depletion have promoted interest in alternative energy resources such as vegetable oil. The change in the global temperature has a serious impact on agricultural production, biodiversity, health and environmental disasters [1]. Biodiesel is a liquid fuel produced from edible and non-edible feedstocks by transesterification [2-5]. Edible-based biodiesel sources are not considered feasible due to price fluctuation, land limitation, and are contrary to the current social movement and energy policies, so their industrial expansion has been limited [6-9]. Although biodiesel production from these sources is inevitable owing to their availability and large production levels, reducing their amounts until using no edible sources will release them for other uses[10-12]. Blending edible/non-edible oils is a solution that will make 
a big contribution towards the advancement of the industry. In addition, Jatropha-palm oil, Jatropha- soapnut and Mahua-simarouba oil blends have been investigated [4, 1317] and observed to be good potential sources for biodiesel production. In Malaysia there are 1,229,940 hectares of rubber plantation according to the Association of Natural Rubber Producing Countries and the projected annual production is estimated to be 1.2 million metric tonnes per year [18]. The trees yield an average of 800 seeds $(1.3 \mathrm{~kg})$ twice a year depending on crop density and soil fertility. The kernels have an average oil content of 30-40 wt. \% and can be used for biodiesel synthesis, with the advantages of less sulfur content, and seedcake that can be used as fertilizer for soil enrichment. Pandian et al. [19] studied the injection pressure (IP), injection timing (IT) and nozzle tip protrusion effect on the performance and emissions parameters of a twin-cylinder diesel engine fuelled with pongamia biodiesel diesel blend using RSM. It was observed that at IP of 225 bar, IT of $30^{\circ}$ BTDC (before top dead center) and nozzle tip protrusion of $2.5 \mathrm{~mm}$, levels of BTE and NOx were higher, while BSFC, unburned hydrocarbon (HC), $\mathrm{CO}$, and smoke were lower.

Raheman and Ghadge [20] investigated engine performance using biodiesel at varying compression ratios of 18,19 and 20. They claimed that the BTE and exhaust gas temperature increased, while the BSFC decreased as the compression ratio increased. Puhan et al. [21] evaluated the effect of injection pressure on engine performance and emissions using methyl ester of linseed oil. It was observed that at the optimum IP of 240 bar, the BSFC and BTE were close to those of diesel, while CO and HC decreased and NOx increased. Hirkude and Padalkar [22] studied engine performance optimization when fuelled with a waste fried oil methyl ester diesel blend using RSM. It was observed that the optimum performance was at IP of 250 bar, IT of $27^{\circ}$ BTDC and compression ratio of 17.99. Based on the literature, various methods were used to study parametric effects on engine performance, such as RSM and neural networks, whereas other authors attempted to study the effects of parameters independently. However, the combined effects of operating variables such as load, speed and blend ratio using a rubber seed/palm oil mixture are still lacking. Therefore, this study aimed to investigate the individual and combined effects of speed, load and blend ratio on the performance of an unmodified indirect diesel engine employing rubber seed/palm oil mixture biodiesel-diesel blends as fuel using RSM.

\section{METHOD AND MATERIALS}

\section{Biodiesel Production and Fuel Properties}

Rubber seed oil and palm oil were purchased from Felcra Chemicals (M) and Kinetics Chemicals (M) Sdn. Bhd. respectively, while the chemicals and reagents were from Sigma Aldrich Malaysia. Diesel fuel was obtained from a local station. Rubber seed and palm oil at 50:50 vol. \% were mixed homogeneously using a mechanical stirrer at 2500 $\mathrm{rpm}$ for $20 \mathrm{~min}$ and the oil acid value of $33.4 \mathrm{mg} \mathrm{KOH} / \mathrm{g}$ oil was reduced to $1.42 \mathrm{mg}$ $\mathrm{KOH} / \mathrm{g}$ oil using the acid esterification process. The oil was then used for the transesterification process using a hydrodynamic cavitation reactor. The reaction variables were temperature of $60{ }^{\circ} \mathrm{C}$, oil to methanol ratio of $1: 8, \mathrm{KOH}$ catalyst of $1 \%$ by oil weight and time of 2 hours, following the conventional biodiesel production method. The reaction was stopped after two hours and the sample was left for gravitational separation. Two layers, glycerol and biodiesel, were obtained after six hours. The obtained biodiesel was washed with warm de-ionized water and then stored 
for study of the fuel properties. The biodiesel properties were measured as presented in Table 1.

Table 1. Biodiesel properties.

\begin{tabular}{llll}
\hline Property & Instruments and methods & Biodiesel & $\begin{array}{l}\text { ASTM D } \\
6751\end{array}$ \\
\hline Density at $25{ }^{\circ} \mathrm{C} \mathrm{kg} / \mathrm{m}^{3}$ & Anton Paar DMA 4500M & 874 & N/A \\
Viscosity at $\mathrm{mm}^{2} / \mathrm{s}, 40{ }^{\circ} \mathrm{C}$ & Anton Paar ASTM 445 & 4.8 & $1.9-6.0$ \\
Calorific value $(\mathrm{MJ} / \mathrm{kg})$ & Pump calorimeter & 38.4 & - \\
Cetane number & ASTM D 613 & 52.19 & $47 \mathrm{~min}$ \\
Oxidation stability (h) & 873-CH-9101 Metrohm EN14112 & 8.92 & $3 \mathrm{~min}$ \\
Flash point $\left({ }^{\circ} \mathrm{C}\right)$ & ASTM D 93 & 150 & 93 min \\
Cloud point $\left({ }^{\circ} \mathrm{C}\right)$ & CPP 5G's ASTM D 2500 & 5 & - \\
Pour point $\left({ }^{\circ} \mathrm{C}\right)$ & CPP 5G's ASTM D 97 & -1 & - \\
Cold filter plugging $\left({ }^{\circ} \mathrm{C}\right)$ & FPP 5G's ASTM D 6371 & 0 & - \\
Moisture content $(\%)$ & ASTM D 2709 & 0.02 & 0.05 max \\
Ester content $(\%)$ & EN 14103 & 98.113 & N/A \\
\hline
\end{tabular}

\section{Engine Test Procedure}

The experiments were performed in a multi-cylinder, naturally aspirated, water-cooled indirect injection diesel engine, XLD418D model. The detailed engine specification and the experimental setup are presented in Table 2 and Figure 1. An eddy current dynamometer, model SE 150, water-cooled, rated power of $150 \mathrm{~kW}$, maximum torque of $500 \mathrm{Nm}$ and maximum speed of $8000 \mathrm{rev} / \mathrm{min}$, was used.

The engine and dynamometer were controlled by a control panel equipped with data acquisition, logging and sensors. The sensors measured the engine speed, torque, power, lubrication oil pressure and temperature, air flow, coolant inlet and outlet temperature and brake specific fuel consumption. The experiments were conducted in part and full load at engine speeds of 1000-4000 rpm. During the experiment, the engine was allowed to warm up for about $15 \mathrm{~min}$ and fuel lines were cleaned by flushing with neat diesel.

Table 2. Engine specifications.

\begin{tabular}{ll}
\hline \multicolumn{1}{c}{ Items } & \multicolumn{1}{c}{ Description } \\
\hline Engine & Diesel engine \\
Model & XLD 418D \\
Type & Four-stroke, 44 kW at 4800 rpm \\
Cylinder number & 4 in line OHC, water cooling pressurized circulation \\
Combustion & IDI, naturally aspirated \\
Bore $\times$ stroke & $82.5 \times 82 \mathrm{~mm}$ \\
Displacement & $1753 \mathrm{cc}$ \\
Compression ratio & $21.5: 1$ \\
\hline
\end{tabular}




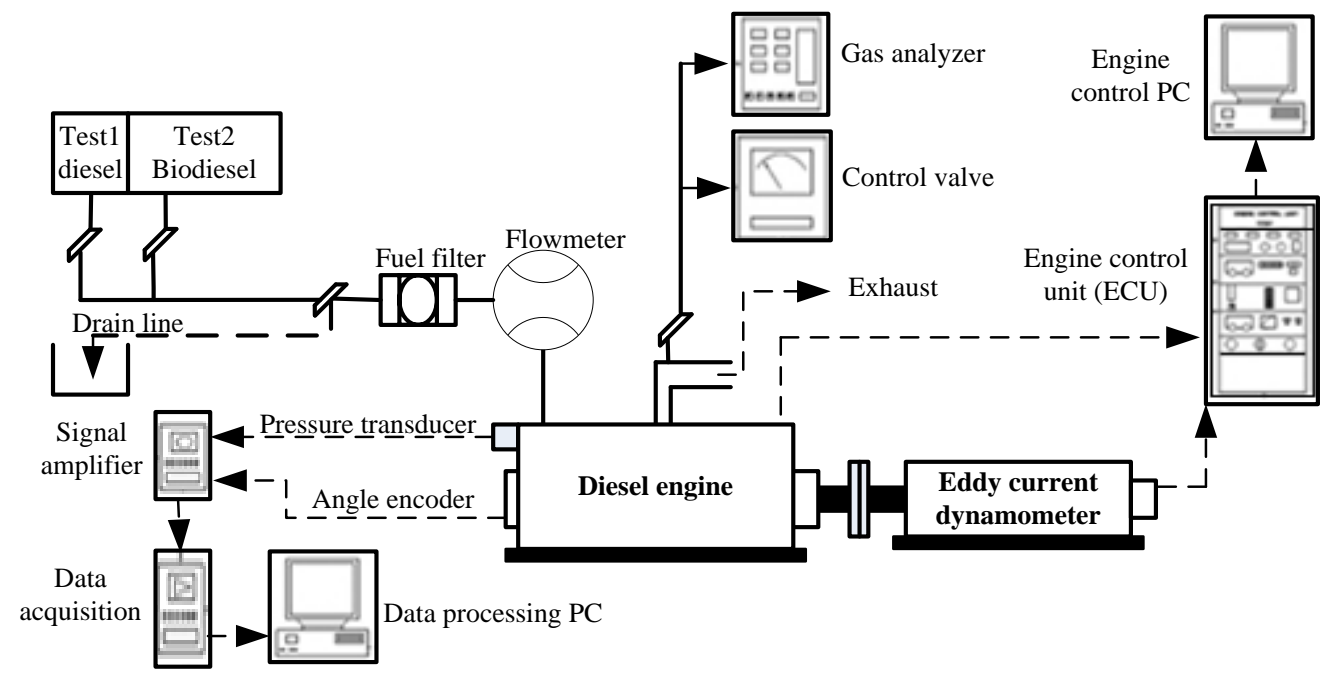

Figure 1. Engine testing setup.

\section{Response Surface Methodology}

RSM is a mathematical tool that is useful for the modeling and analysis of problems in which the interest is influenced by various variables. It provides an experimentation strategy for building and optimizing the model [23]. The Box-Behnken design is a rotatable design that considers the midpoint of factor edges and the center point as treatment combinations [24]. These designs require three levels of each factor to identify whether the selected factors are significant or not. The number of experiments required by Box-Behnken is calculated using Eq. (1).

$$
n=2 k(k-1)+\mathrm{C}_{0}
$$

where $n=$ number of experiments, $k=$ factor number and $\mathrm{C}_{0}=$ number of center points. In the current work, the Box-Behnken design was chosen because it requires fewer experiments to be run and is easier to arrange or interpret. In this study, Design Expert version 8.0.6 by Stat-Ease, US, was applied. The number of factors was 3 and there were 5 center points, as shown in Table 3. The total experimental runs were 17, as shown in Table 4. Based on the running order, the experiments were conducted and the data collected were fed into the Design Expert software. A multi regression analysis using a second order polynomial was studied. The coefficients and equation used to predict the responses were obtained based on statistical significance. Finally, the correlations between the factors and the responses were obtained. The second order polynomial is presented in Eq. (2).

$$
\mathrm{y}=\beta_{0}+\sum_{\mathrm{i}=1}^{3} \beta_{\mathrm{i}} \mathrm{X}_{\mathrm{i}}+\sum_{\mathrm{i}=1}^{3} \beta_{i i} X_{i}^{2}+\sum_{i=1}^{2} \sum_{j=i+1}^{3} \beta_{i j} X_{i} X_{j}
$$

where $\mathrm{y}$ is predicted response variable, $\mathrm{X}_{\mathrm{i}}$ is independent variable, $\beta_{0}=$ interception coefficient, $\beta_{\mathrm{i}}=$ linear coefficient, $\beta_{i i}=$ quadratic coefficient and $\beta_{i j}=$ interaction coefficient between variable $i$ and $j$.

Table 3. Factors parameters . 


\begin{tabular}{lcccc}
\hline Variables & Designation & \multicolumn{3}{c}{ Levels } \\
\cline { 3 - 5 } & & -1 & 0 & 1 \\
\hline Blend (vol. \%) & $\mathrm{A}$ & 0 & 10 & 20 \\
Speed (rpm) & $\mathrm{B}$ & 1000 & 2500 & 4000 \\
Load (\%) & $\mathrm{C}$ & 40 & 70 & 100 \\
\hline
\end{tabular}

Table 4. Experiments design matrix.

\begin{tabular}{cccccccc}
\hline \multicolumn{4}{c}{ Variables } & \multicolumn{4}{c}{ Response } \\
\hline Run & A & B & C & $\begin{array}{l}\text { Torque } \\
(\mathrm{Nm})\end{array}$ & $\begin{array}{l}\text { Power } \\
(\mathrm{kW})\end{array}$ & $\begin{array}{l}\mathrm{BSFC} \\
(\mathrm{g} / \mathrm{kWh})\end{array}$ & $\begin{array}{l}\mathrm{BTE} \\
(\%)\end{array}$ \\
\hline 1 & 10 & 1000 & 100 & 71 & 7.4 & 467.7 & 18.2 \\
2 & 20 & 2500 & 100 & 78 & 20.4 & 340.6 & 27.0 \\
3 & 10 & 4000 & 100 & 78 & 31.4 & 347.0 & 24.5 \\
4 & 10 & 2500 & 70 & 71 & 17.5 & 284.5 & 27.2 \\
5 & 20 & 4000 & 70 & 70 & 29.4 & 315.1 & 26.6 \\
6 & 10 & 2500 & 70 & 71 & 17.5 & 284.5 & 27.2 \\
7 & 10 & 2500 & 70 & 71 & 17.5 & 284.5 & 27.2 \\
8 & 10 & 1000 & 40 & 38 & 4.0 & 641.0 & 13.3 \\
9 & 20 & 1000 & 70 & 67 & 7.3 & 473.3 & 18.1 \\
10 & 10 & 2500 & 70 & 71 & 17.5 & 284.5 & 27.2 \\
11 & 0 & 2500 & 100 & 86 & 22.5 & 305.2 & 27.7 \\
12 & 10 & 2500 & 70 & 71 & 17.5 & 284.5 & 27.2 \\
13 & 0 & 1000 & 70 & 73 & 7.6 & 360.1 & 21.6 \\
14 & 0 & 4000 & 70 & 71 & 29.6 & 297.3 & 26.1 \\
15 & 0 & 2500 & 40 & 41 & 10.7 & 319.2 & 26.5 \\
16 & 10 & 4000 & 40 & 41 & 17.1 & 383.9 & 22.1 \\
17 & 20 & 2500 & 40 & 39 & 11.2 & 308.0 & 26.1 \\
\hline
\end{tabular}

\section{RESULTS AND DISCUSSION}

\section{Analysis and Model Evaluation}

In this study, the analysis of variance (ANOVA) was used to evaluate the engine performance significance test, as shown in Table 5. The model is assumed to be significant if the $p$-value is less than 0.05 at $95 \%$ confidence level $[19,22,25]$. From Table 5 it is seen that the models are all significant, as the p-value $<0.001$, which means that the models are able to explain $95 \%$ of the response variability. The polynomial quadratic models for the responses were developed in terms of coded factors and are presented in Eqs.(3)-(6). In order to evaluate the statistical quadratic model fitting to the experimental data, the regression model significance test, lack of fit and individual model coefficients were studied, as shown in Table 6. The data fitting quality was expressed in terms of determination coefficient $\left(\mathrm{R}^{2}\right)$ and goodness of prediction (Adj$\left.\mathrm{R}^{2}\right)$. However, as the number of variables increases, the determination coefficient $\left(\mathrm{R}^{2}\right)$ increases. Hence, it is recommended to use adj- $R^{2}$, which decreases if unnecessary terms are added. Furthermore, the lack of fit test was found not to be significant for all responses at $95 \%$ confidence level. To study the combined effect of the factors on any 
response, 3D graphs were plotted, where each fitting model is a function of two factors, while the other factor was set at the center point of its range (A: 10 vol. \%, B: $2500 \mathrm{rpm}$ and C: $70 \%$ respectively).

Table 5. ANOVA evaluation for the responses indicating p-value.

\begin{tabular}{ccccc}
\hline Source & Torque & Power & BSFC & BTE \\
\hline Model & $<0.0001$ & $<0.0001$ & 0.0036 & 0.0007 \\
A & 0.0325 & 0.5002 & 0.2093 & 0.0611 \\
B & 0.1289 & $<0.0001$ & 0.0011 & 0.0006 \\
C & $<0.0001$ & $<0.0001$ & 0.1318 & 0.2442 \\
AB & 0.3052 & 0.9632 & 0.2689 & 0.0884 \\
AC & 0.2260 & 0.2533 & 0.5761 & 0.2716 \\
BC & 0.4055 & 0.0012 & 0.1296 & 0.4548 \\
A $^{2}$ & 0.1836 & 0.0675 & 0.1387 & 0.2069 \\
B $^{2}$ & 0.0680 & 0.8131 & 0.0008 & $<0.0001$ \\
C $^{2}$ & $<0.0001$ & 0.0022 & 0.0112 & $<0.0011$ \\
\hline
\end{tabular}

Table 6. Response surface model evaluation.

\begin{tabular}{ccccc}
\hline Model & Torque & Power & BSFC & BTE \\
\hline Mean & 67.98 & 17.88 & 339.66 & 26.14 \\
Std. deviation & 3.94 & 0.81 & 40.54 & 1.56 \\
C.V & 5.80 & 4.51 & 11.94 & 5.97 \\
Model degree & Quadratic & Quadratic & Quadratic & Quadratic \\
Lack of fit & 0.14 & 0.36 & 0.92 & 0.11 \\
R $^{2}$ & 0.9785 & 0.9965 & 0.9266 & 0.9631 \\
Adj. R & 0.9509 & 0.9919 & 0.8323 & 0.9156 \\
Pred. $\mathrm{R}^{2}$ & 0.8569 & 0.9432 & 0.8139 & 0.8201 \\
\hline
\end{tabular}

Torque $=71.00-2.13 \times \mathrm{A}+1.37 \times \mathrm{B}+19.25 \times \mathrm{C}+1.25 \times \mathrm{A} \times \mathrm{B}-1.50 \times \mathrm{A} \times \mathrm{C}$

$$
+1.00 \times \mathrm{B} \times \mathrm{C}+1.63 \times \mathrm{A}^{2}-2.38 \times \mathrm{B}^{2}-11.63 \times \mathrm{C}^{2}
$$

$$
\begin{gathered}
\text { Power }=17.50-0.26 \times A+10.15 \times B+4.84 \times C+0.025 \times A \times B-0.65 \times A \times C \\
+2.73 \times B \times C+1.10 \times A^{2}-0.13 \times B^{2}-2.40 \times C^{2}
\end{gathered}
$$

$\mathrm{BSFC}=284.46+19.41 \times \mathrm{A}-74.86 \times \mathrm{B}-23.95 \times \mathrm{C}-23.84 \times \mathrm{A} \times \mathrm{B}+11.64 \times \mathrm{A} \times \mathrm{C}$ $+34.10 \times \mathrm{B} \times \mathrm{C}-32.33 \times \mathrm{A}^{2}+109.31 \times \mathrm{B}^{2}+66.13 \times \mathrm{C}^{2}$

$$
\begin{gathered}
\mathrm{BTE}=29.90-1.28 \times \mathrm{A}+3.37 \times \mathrm{B}+0.73 \times \mathrm{C}+1.60 \times \mathrm{A} \times \mathrm{B}-0.97 \times \mathrm{A} \times \mathrm{C} \\
-0.64 \times \mathrm{B} \times \mathrm{C}+1.10 \times \mathrm{A}^{2}-6.14 \times \mathrm{B}^{2}-4.23 \times \mathrm{C}^{2}
\end{gathered}
$$

\section{Interactive Effect of Blends, Engine Speed and Load}

The interactive effect of blend, speed and load on the responses such as torque, power, BSFC and BTE are shown in Figures 2-5 respectively. In Figure 2, initially the torque increased as the engine speed and load increased and reached a maximum point before decreasing with further increase in speed (Figure 2(a)). Compared to fossil diesel fuel, 
the blends' torque was $1 \%$ lower. The reduction of the blends' torque was mainly due to their higher viscosity, lower volumetric efficiency and lower heating values [27]. The maximum torque is obtained at the speed range of $2000-3000 \mathrm{rpm}$, due to the engine's inability to ingest the full air charge. From Table 5 it is seen that speed and load had a stronger effect on the response compared to the blend, because the p-values were greater than the reference value of 0.05 . The individual and combined effects of variables on torque were only noticed over blend and load, whereas no speed effect was observed.
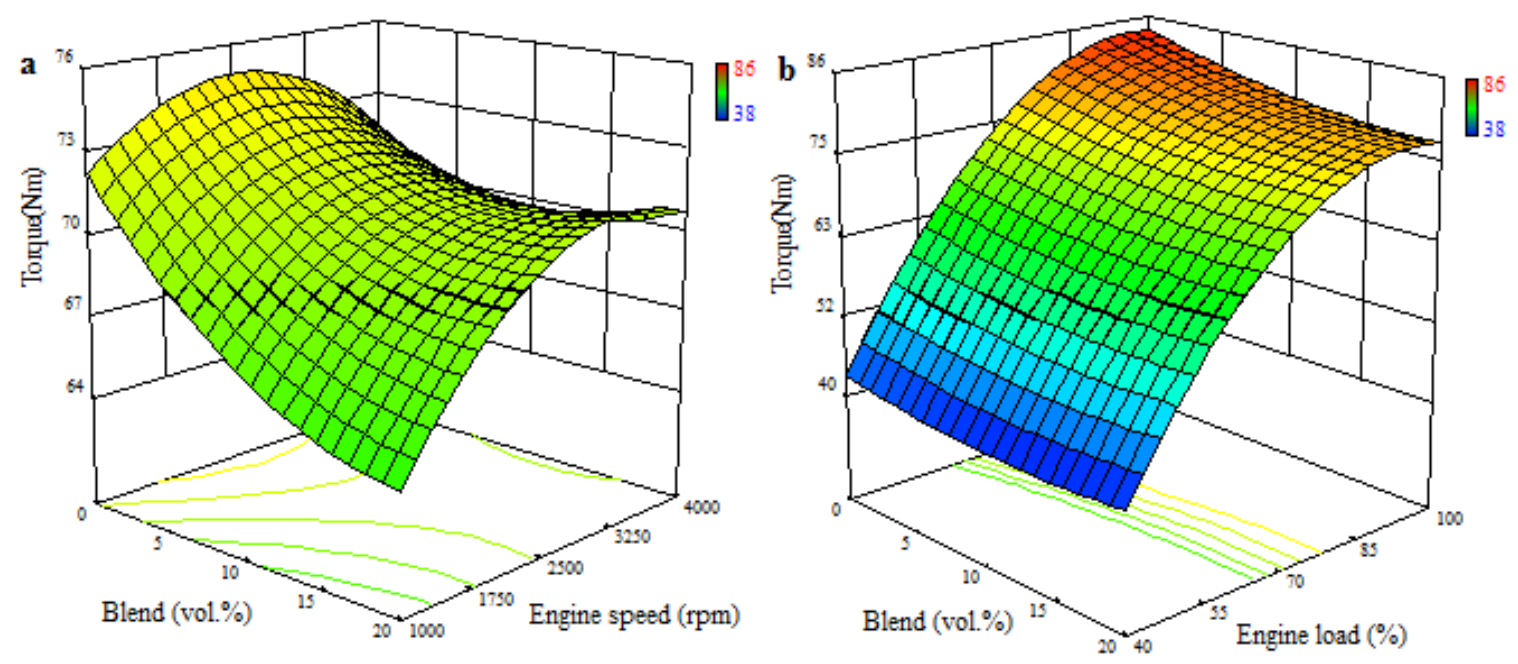

Figure 2. Torque variations against (a) blend and speed; (b) blend and load.

The surface plot of power as a function of speed, blend ratio and load is shown in Figure 3. It is clear that the power trend increased initially as the speed and load increased. It is noticeable that at lower speeds of less than $3000 \mathrm{rpm}$ and lower loads less than $60 \%$, the power tendency is relatively similar. The increasing power is because of the oxygen content, $12.77 \%$ (in weight) for the obtained methyl ester [28], or due to the volumetric pumping basis of the diesel engine; as the density increased a large mass flow rate could be injected into the cylinder, resulting in higher power. However, the power difference is more noticeable at higher load and speed. The reduction at higher speed is because of the engine's inability to ingest the full charge of air and increased frication losses [29]. The ANOVA analysis in Table 5 indicated that speed, load and their combination are the most significant variables compared to the blend ratio, as the p-values are less than 0.05. Brake specific fuel consumption values across the engine speed, blend ratio and load are shown in Figure 4. It is observed that the BSFC for all the tested fuels has a tendency to decrease as the speed and load increase, due to higher brake power development compared to the losses, or because the engine is in the idle condition. At lower speed and lower load, the BSFC was proportionally higher than the blends ratio. This is because of the increased density and lower heating value, which results in more fuel being injected to produce the same power [30-33].

Engine BTE with respect to the speed, load and blends ratio is presented in Figure 5. It is observed that the BTE has a tendency to increase as the speed and load increase, and reaches a maximum value before decreasing with further increase in speed and load. The engine BTE was improved due to the additional lubricity provided by the oxygen content in the biodiesel, which takes part in the combustion process. The BTE 
was found to decrease as the biodiesel ratio increased due to the higher viscosity and poor volatility, leading to poor atomization and combustion characteristics [32].
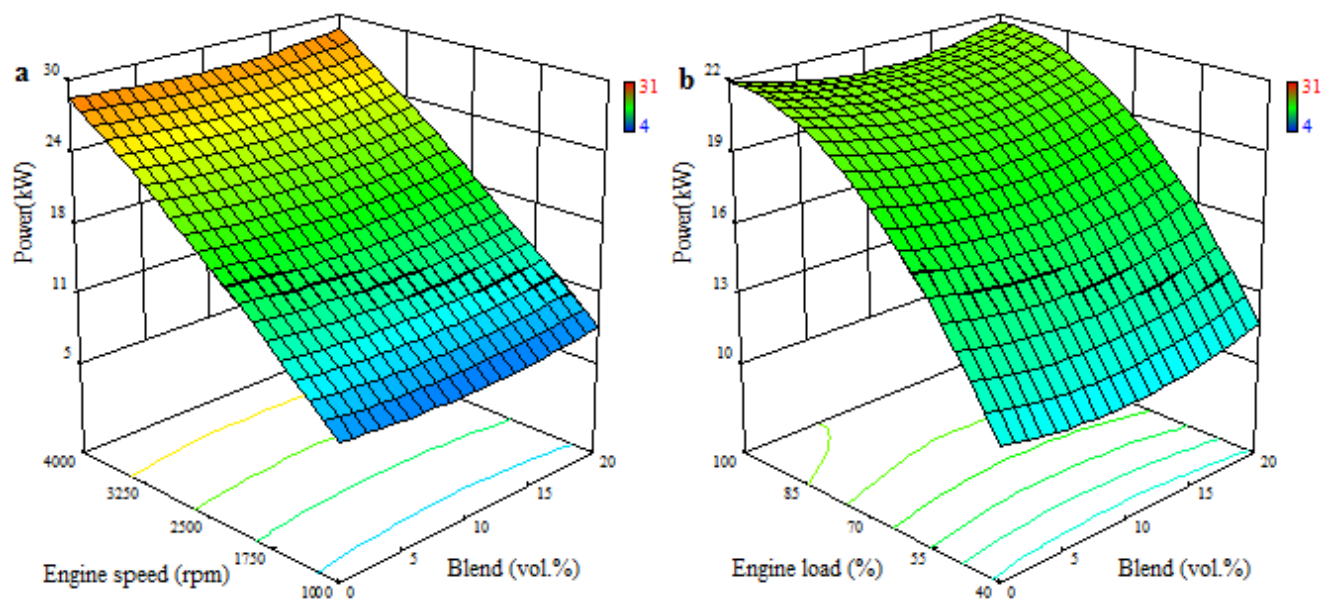

Figure 3. Power variations against (a) blend and speed; (b) blend and load.
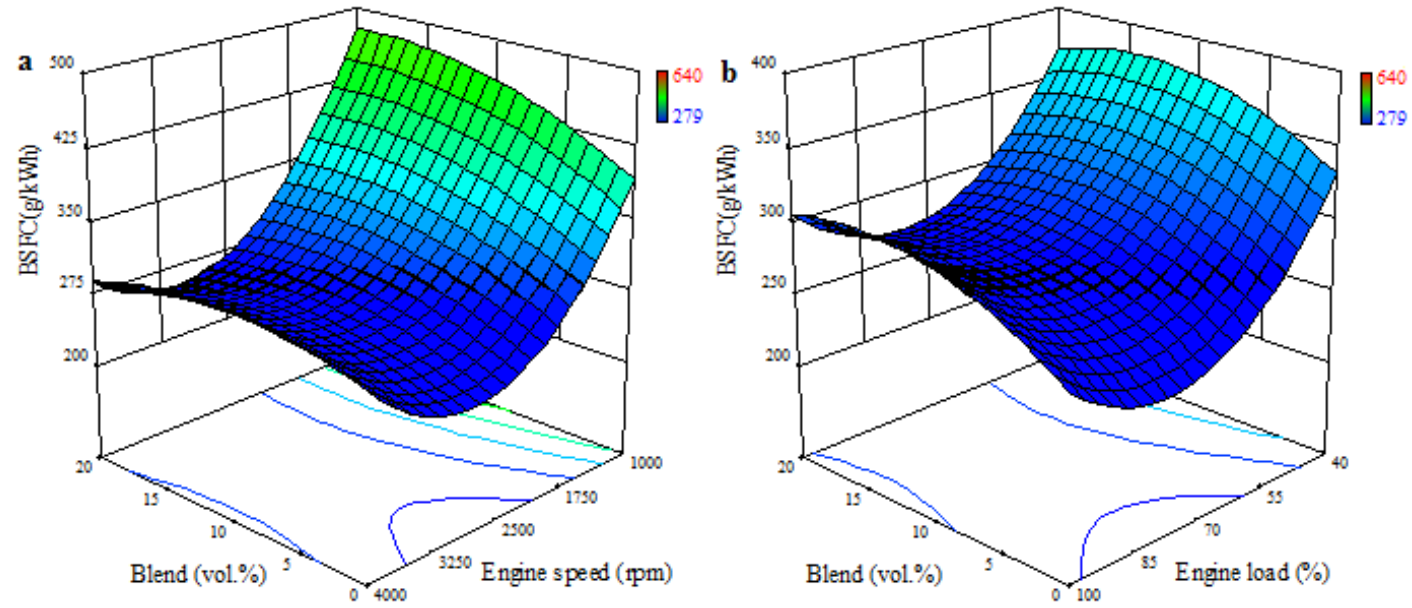

Figure 4. BSFC variations against (a) blend and speed; (b) blend and load.
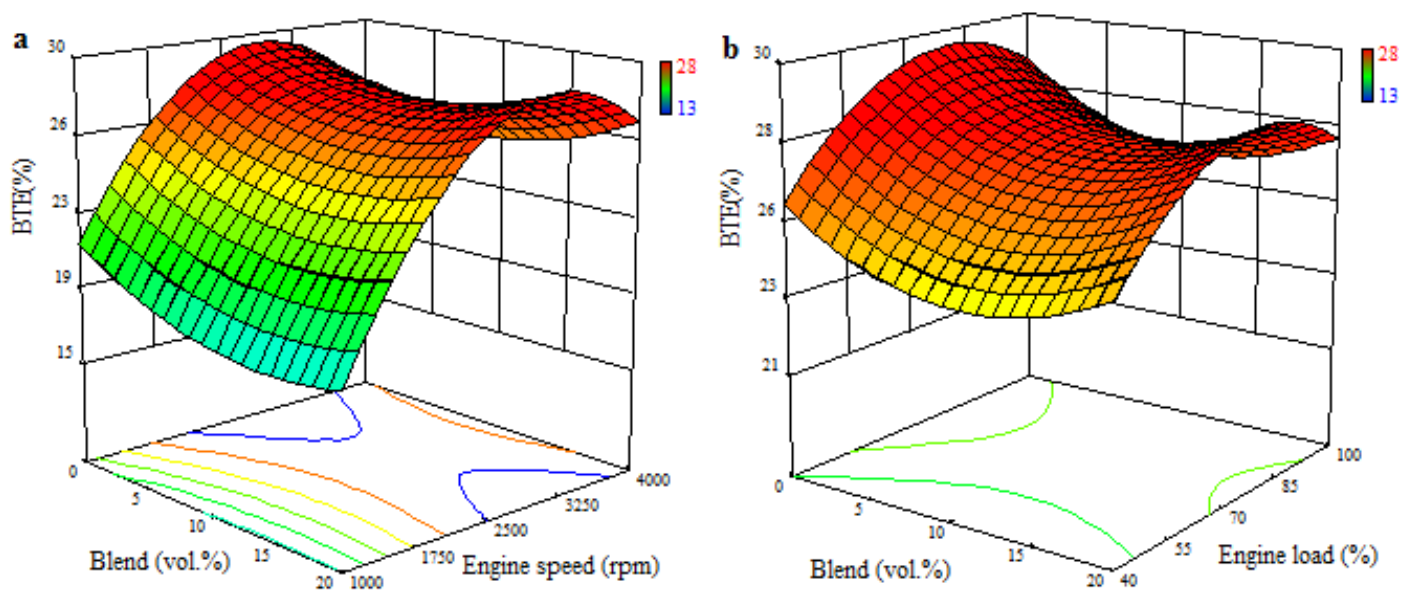

Figure 5. BTE variations against (a) blend and speed; (b) blend and load. 


\section{CONCLUSIONS}

The combined effects of speed, load and blend ratio on the indirect diesel engine performance when fuelled by a rubber seed/palm oil mixture based biodiesel were performed statistically by means of the response surface methodology. The following conclusions were reached in this investigation. Design of experiments was observed to be very helpful in designing the experimental matrix, and analyzing and identifying the factors with the most influence on the performance. The blends torque, power and BTE were lower but the BSFC was higher. The reason for this is the lower heating values of the blends, which result in more fuel being injected into the cylinder, and hence the higher BSFC. The effect of speed over all the responses was seen to be significant except for torque, with the $\mathrm{p}$-value $>0.05$, whereas its combined effect was insignificant except for BSFC and BTE. Load as an individual and combined variable was observed to contribute significantly for all the tested responses as compared to speed and blend. However, no significant contribution was found for the blend except for torque.

\section{ACKNOWLEDGMENTS}

The authors would like to acknowledge the Ministry of Education Malaysia for providing Myra fund (COE-0153AB-J07) and Universiti Teknologi PETRONAS for the facilities to conduct this research work.

\section{REFERENCES}

[1] Naseer AK, elDessouky H. Prospect of biodiesel in Pakistan. Renewable and Sustainable Energy Reviews. 2009;13:1576-83.

[2] Ahmad J, Yusup S, Bokhari A, Kamil RNM. Study of fuel properties of rubber seed oil based biodiesel. Energy Conversion and Management. 2014;78:266-75.

[3] Abbaszadeh A, Ghobadian B, Najafi G, Yusaf T. An experimental investigation of the effective parameters on wet washing of biodiesel purification. International Journal of Automotive and Mechanical Engineering. 2014;9:152537.

[4] Nayak C, Pattanaik BP, Nayak SK. Effect of preheated jatropha oil and jatropha oil methyl ester with producer gas on diesel engine performance. International Journal of Automotive and Mechanical Engineering. 2014;9:1709-22.

[5] Nematizade P, Ghobadian B, Najafi G. Investigation of fossil fuels and liquid biofuels blend properties using artificial neural network. International Journal of Automotive and Mechanical Engineering. 2012;5:639-47.

[6] Ng WPQ, Lam HL, Yusup S. Supply network synthesis on rubber seed oil utilisation as potential biofuel feedstock. Energy. 2013;55:82-8.

[7] Yusaf T, Hamawand I, Baker P, Najafi G. The effect of methanol-diesel blended ratio on CI engine performance. International Journal of Automotive and Mechanical Engineering. 2013;8:1385-95.

[8] Azman SR, Ismail M, Kadhum AAH, Yaakob Z. The Performance of Monolithic Structured Calcium Oxide for Biodiesel. International Journal of Automotive and Mechanical Engineering. 2014;10:1959-70.

[9] Rostami S, Ghobadian B, Kiani Deh Kiani M. Effect of the injection timing on the performance of a diesel engine using Diesel-Biodiesel blends. International Journal of Automotive and Mechanical Engineering. 2014;10:1945-58. 
[10] Rahim R, Mamat R, Taib MY, Abdullah AA. Influence of fuel temperature on a diesel engine performance operating with biodiesel blended. Journal of Mechanical Engineering and Sciences. 2012;2:226-36.

[11] Nasir N, Daud Z. Performance of Aluminium sulphate and polyaluminium choloride in biodiesel wastewater. Journal of Mechanical Engineering and Sciences. 2014;7:1189-95.

[12] Yusop AF, Mamat R, Mat Yasin MH, Ali OM. Effects of particulate matter emissions of diesel engine using diesel-methanol blends. Journal of Mechanical Engineering and Sciences. 2014;6:959-67.

[13] Sarin R, Sharma M, Sinharay S, Malhotra RK. Jatropha - Palm biodiesel blends : An optimum mix for Asia. Fuel. 2007;86:1365-71.

[14] Sarin A, Arora R, Singh NP, Sarin R, Malhotra RK, Kundu K. Effect of blends of Palm-Jatropha-Pongamia biodiesels on cloud point and pour point. Energy. 2009;34:2016-21.

[15] Sarin A, Arora R, Singh NP, Sarin R, Malhotra RK. Blends of biodiesels synthesized from non-edible and edible oils: Influence on the OS (oxidation stability). Energy. 2010;35:3449-53.

[16] Raheman HJ, Prakash C. Jadav, Snehal S. Performance of a diesel engine with blends of biodiesel ( from a mixture of oils ) and high-speed diesel. International Journal of Energy and Environmental Engineering. 2013;4:1-.

[17] Chen YH, Chiang TH, Chen JH. An optimum biodiesel combination: Jatropha and soapnut oil biodiesel blends. Fuel. 2012;92:377-80.

[18] Eka HD, Tajul Aris, Y. Wan Nadiah, W. A. Potential use of Malaysian rubber (Hevea brasiliensis) seed as food, feed and biofue. International Food Research Journal 2010;17:527-34.

[19] Pandian M., Sivapirakasam S.P., Udayakumar M. Investigation on the effect of injection system parameters on performance and emission characteristics of a twin cylinder compression ignition direct injection engine fuelled with pongamia biodiesel-diesel blend using response surface methodology. Applied Energy. 2011;88:2663-76.

[20] Raheman H., Ghadge SV. Performance of diesel engine with biodiesel at varying compression ratio and ignition timing. Fuel. 2008;87:2659-66.

[21] Puhan S, Jegan R, Balasubbramanian K, Nagarajan G. Effect of injection pressure on performance, emission and combustion characteristics of high linolenic linseed oil methyl ester in a DI diesel engine. Renewable Energy. 2009;34:1227-33.

[22] Jagannath B H, Atul S. Padalkar. Performance optimization of CI engine fuelled with waste fried oil methyl ester-diesel blend using response surface methodology. Fuel. 2014;199:266-73.

[23] Deniz Bas, Boyac1 IH. Modeling and optimization I: Usability of response surface methodology. Journal of Food Engineering 2007;78:836-45.

[24] Marcos Almeida Bezerraa, Ricardo Erthal Santelli, Oliveira EP, Leonardo Silveira Villar, Escaleira LAe. Response surface methodology (RSM) as a tool for optimization in analytical chemistry. Talanta. 2008;76:965-77.

[25] Jagannath Hirkude, Atul Padalkar, Shafee Shaikh, Veigas1 A. Effect of compression ratio on performance of CI engine fuelled with biodiesel from waste fried oil using response surface methodology. International Journal of Energy Engineering. 2013;3:227-33. 
[27] Gokalp B, Buyukkaya E, Soyhan HS. Performance and emissions of a diesel tractor engine fueled with marine diesel and soybean methyl ester. Biomass and Bioenergy. 2011;35:3575-83.

[28] Kalam MA, Husnawan M, Masjuki HH. Exhaust emission and combustion evaluation of coconut oil-powered indirect injection diesel engine. Renewable Energy. 2003;28:2405-15.

[29] Kalam MA, Masjuki HH, Jayed MH, Liaquat AM. Emission and performance characteristics of an indirect ignition diesel engine fuelled with waste cooking oil. Energy. 2011;36:397-402.

[30] Ramadhas AS, Muraleedharan C, Jayaraj S. Performance and emission evaluation of a diesel engine fueled with methyl esters of rubber seed oil. Renewable Energy. 2005;30:1789-800.

[31] Michael S. Graboski, McCormick RL. Combustion of fat and vegetable oil derived fuels in diesel engine Progress in Energy and Combustion Science. 1998;24:125-64.

[32] Labecki L, Cairns A, Xia J, Megaritis A, Zhao H, Ganippa LC. Combustion and emission of rapeseed oil blends in diesel engine. Applied Energy.2012;95:13946.

[33] Qi DH, Lee CF, Jia CC, Wang PP, Wu ST. Experimental investigations of combustion and emission characteristics of rapeseed oil-diesel blends in a two cylinder agricultural diesel engine. Energy Conversion and Management 2014;77:227-32. 